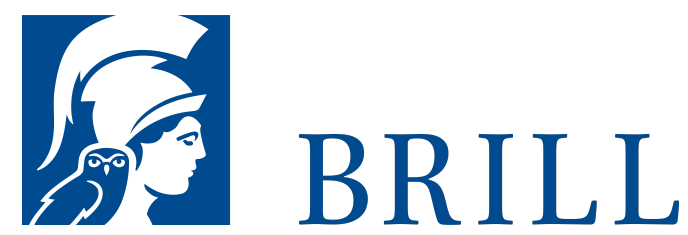

\title{
Das Gettierproblem
}

Eine Bilanz nach 5 o Jahren

Authors: Gerhard Ernst and Lisa Marani

Vor 50 Jahren hat Gettier seinen berühmten Dreiseitenaufsatz veröffentlicht und damit einen wesentlichen Impuls für die moderne analytische Erkenntnistheorie gegeben. Aber: Was genau ist eigentlich das Gettierproblem? Ist es ein "tiefes" Problem oder eher eine Spielerei? Und wie sieht noch einmal die richtige Lösung aus? Ist das Problem überhaupt gelöst oder eher eingeklammert worden? Stand es überhaupt zu Recht so lange im Mittelpunkt der analytischen Erkenntnistheorie? Oder war das Gettierproblem eher eine Sackgasse und hat von wichtigeren Fragen abgelenkt? Wie steht das Gettierproblem zu anderen Fragen der Erkenntnistheorie? Diesen und ähnlichen Fragen gehen die Autoren im vorliegenden Sammelband nach. Mit Beiträgen von Peter Baumann, Sven Bernecker, Elke Brendel, Gerhard Ernst, Wolfgang Freitag, Geert Keil, Dirk Koppelberg, Lisa Marani, Wolfgang Spohn, Stefan Tolksdorf

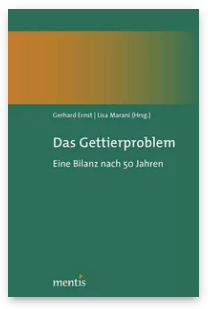

Pages: 222

Seiten

Language:

German

Subjects:

General,

Philosophy

Publisher: Brill | mentis

E-Book (PDF)

Released online:

o5 Dec 2013

ISBN: $978-3^{-}$

89785-470-3

List price

Paperback

Publication date:

o5 Dec 2013

ISBN: 978-3-

89785-840-4

List price 
For more information see brill.com

Order information: Order online at brill.com +44330 333 0049 | customerservices@brill.com Submission information: brill.com/authors

Titles published by Brill | Fink, Brill | mentis or Brill | Schöningh: +49(o)715413279216| brill@brocom.de 